\title{
Auricular Angioleiomyoma: A Case Report
}

\author{
Aurikular Anjioleiomyoma: Olgu Sunumu
}

\author{
Rana ÇiTiL', Harun ÇIRALIK ${ }^{2}$, Asiye GÜL ${ }^{3}$, Hamide SAYAR ${ }^{2}$ \\ 'Pathology Laboratory and ${ }^{3}$ Department of Otolaryngology, Kahramanmaraş State Hospital, KAHRAMANMARAŞ, TURKEY \\ ${ }^{2}$ Department of Pathology, Sütçü Imam University, Faculty of Medicine, KAHRAMANMARAŞ, TURKEY
}

\begin{abstract}
Angioleiomyoma (vascular leiomyoma or angiomyoma) is a rare, benign smooth muscle tumor that originates in the tunica media of blood vessels. These tumors may be found anywhere in the body. They usually occur in the lower extremity. Auricular angioleiomyoma is very rare, and only a few cases have been reported. We describe here a 38-year-old male patient with angioleiomyoma on the left auricular helix.
\end{abstract}

Key Words: Angioleiomyoma, Vascular, Leiomyoma, Ear
ÖZ

Anjiyoleiyomiyoma (vasküler leiyomiyoma veya anjiyomiyoma) nadir görülen, kan damarlarının tunika mediasından köken alan benign düz kas tümörüdür. Bu tümörler vücutta herhangi bir yerde bulunabilir. Sıklıkla alt ekstremitede ortaya çıkmaktadır. Aurikular anjiyoleiyomyoma oldukça nadirdir ve az sayıda olgu rapor edilmiştir. Biz burada sol aurikular helikste anjiyoleiyomiyoması olan 38 yaşındaki bir erkek hastayı sunmaktayız.

Anahtar Sözcükler: Anjiyoleiyomyoma, Vasküler, Leiyomyoma, Kulak

composed of a well circumscribed proliferation of smooth muscle bundles that surrounded numerous thick-walled blood vessels with partially patent lumina (Figure 1). The smooth muscle cells showed no cellular atypia or mitoses. In immunohistochemical studies, the perivascular proliferating smooth muscle cells and the muscular wall

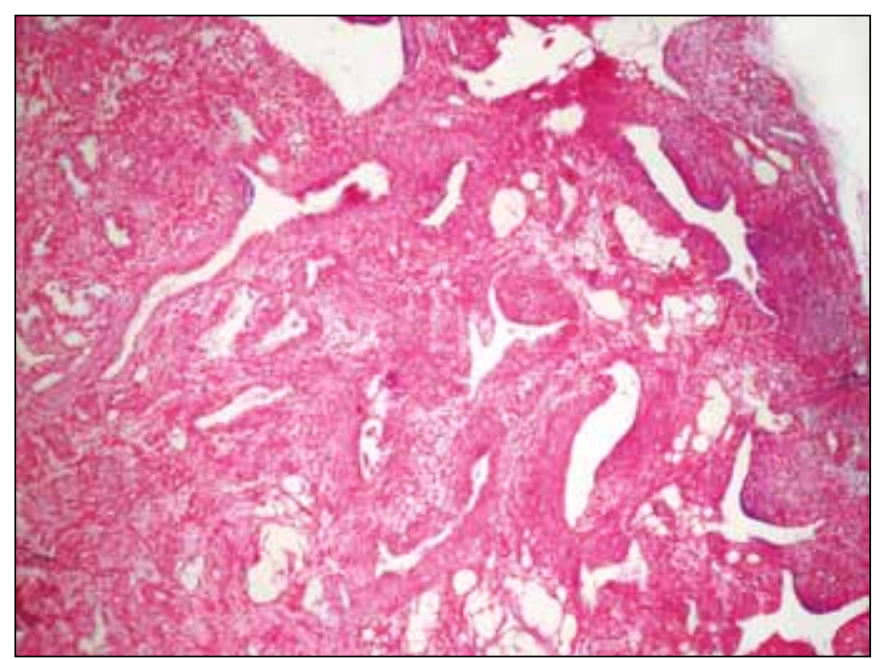

Figure 1: The tumor mass is composed of well-differentiated smooth muscle cells and numerous thick-walled vessels with some dilated vascular channels (H\&E; X40).

Correspondence: Rana ÇíTíL

Pathology Laboratory, Kahramanmaraş State Hospital,

KAHRAMANMARAŞ, TURKEY

E-mail: ranacitil@gmail.com Phone: +90 3442235330 
of thick blood vessels showed immunoreactivity for the smooth muscle antigen (SMA). Smooth muscle stained dark red by Masson's Trichrome (Figure 2). The endothelial cells stained with CD34 antibody (Figure 3). Based on these results, the tumor was diagnosed venous type angioleiomyoma. There was no evidence of recurrence during the six month postsurgical period.

\section{DISCUSSION}

Benign tumors of smooth muscle cells can be categorized in three clinicopathologic varieties: 1- Cutaneous leiomyomas (pilar leiomyoma, genital leiomyoma); 2- Angiomyoma (vascular leiomyoma or angioleiomyoma); 3- Leiomyoma of deep soft tissue (somatic leiomyoma, gynecologic leiomyoma) (7).

Angioleiomyomas, a subtype of leiomyomas, are rare, benign, smooth muscle tumors that arises from tunical media layer of small arteries and veins (5). Leiomyoma was published by Aufrecht in 1868 and it was the first report of a case arising from blood vessels' wall. Angioleiomyoma is classified into three histological types. 1-Capillary or solid: the most common type, which is closely compacted smooth muscle and many small, slit-like vascular channels. 2-Venous: thick, easily identifiable muscular walls distinguish this type. 3- Cavernous: the vascular channels are dilated with less smooth muscle. This is the least common of the three types $(5,8)$.

It may occur anywhere in the skin or subcutaneous tissue. The tumors are usually small ( 2 to $15 \mathrm{~mm}$ ), solitary, round, firm, skin-colored, and well-encapsulated (1).

Hachisuga reviewed 562 cases. Among those cases, 205 cases were male and 357 were female, with a ratio of 1:1.7. The peak incidence was between the fourth and sixth decades (5). Most common anatomical sites are lower extremity (67\%), upper extremity, head and trunk. Solid angioleiomyoma occurs most frequently in the lower extremity of females. The venous type is the most frequent type found in the head and neck region usually in males, as occurred in our case. Pain and tenderness are the most characteristic subjective complaints in patients with angioleiomyoma (\%58) $(5,6)$. Exposure to wind, cold, local pressure and other imperceptible stimuli cause attacks of paroxysmal pain. Painful tumors are the most frequent type of solid tumors. Tumors occurring in the head and neck regions are usually not accompanied by pain (5).

The clinical presentation of angioleiomyoma is nonspecific. It is not easily differentiated from other benign subcutaneous tumors. The diagnosis of this lesion is therefore based on excisional biopsy (3).

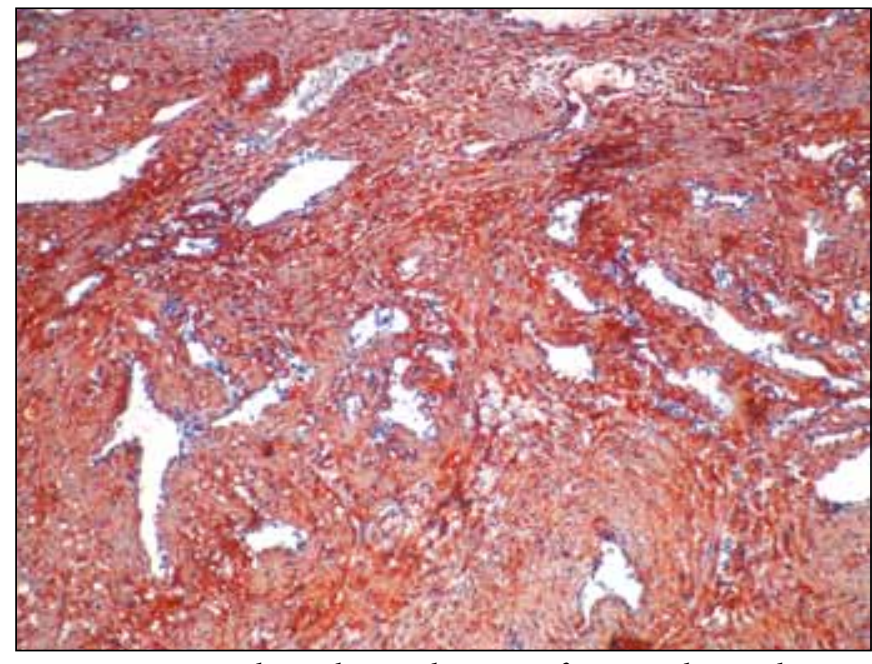

Figure 2: Immunohistochemical staining for smooth muscle actin shows a positive reaction in perivascular proliferating smooth muscle bundles (x100).

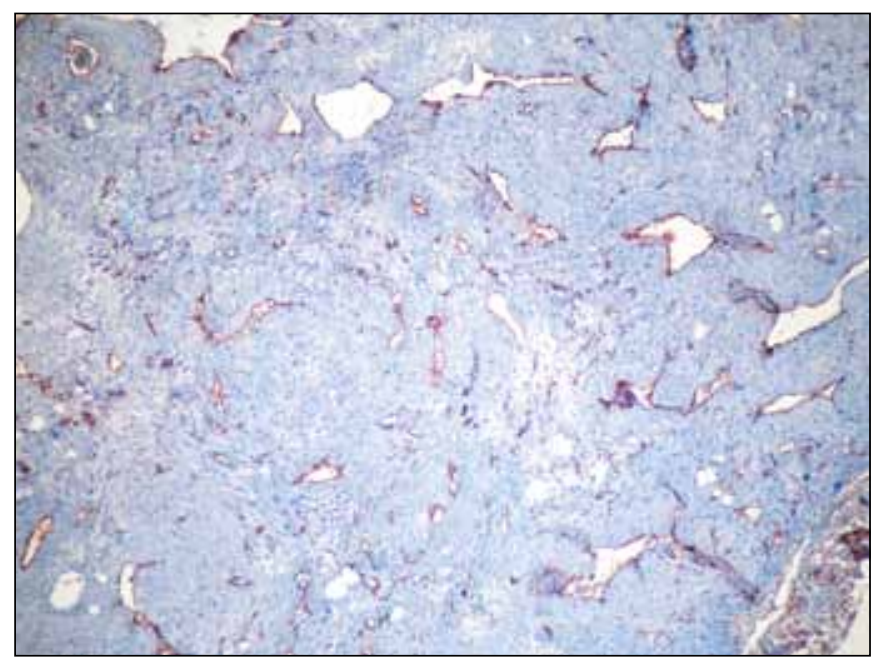

Figure 3: The endothelial cells of the thick-walled vessels stained with CD34 antigen (x40).

Grossly, the tumors are circumscribed, glistening, white-gray nodules. Microscopically, the tumors have a characteristic appearance that varies little from case to case. The usual appearance is a well-demarcated nodule of smooth muscle tissue punctuated with thick-walled vessels with partially patent lumens. Typically, the inner layers of smooth muscle of vessels are arranged in an orderly circumferential fashion and the outer layers spin or swirl away from the vessel, merging with the less well-ordered peripheral muscle fibers. The vessels in these tumors are difficult to classify as veins or arteries (7). Various stains have been used to identify vascular leiomyomas, including; desmin, vimentin, actin, myosin, and Masson's trichrome. 
In our patient, the tumor intensely stained with smooth muscle actin and Masson's trichrome.

Recurrence after excision is rare (5). Malignant changes have been reported in recurrent tumors (9). There is one case report that an angioleiomyoma can occur in association with a leiomyosarcoma (10).

In this article, we describe a case of angioleiomyoma arising from the auricle. This lesion should be considered in the differential diagnosis of nodular masses of the auricle. The pathological differential diagnosis must include subcutaneus leiomyoma, hemangioma, angiofibroma, fibromyoma, leiomyoblastoma, angiomyolipoma, vascular leiomyosarcoma and other tumors of perivascular cells (glomus tumors and myopericytoma) $(11,12)$.

\section{REFERENCES}

1. Inoue F, Matsumoto K: Vascular leiomyoma of the auricle. Arch Dermatol 1983, 119:445-446

2. Choe KS, Sclafani AP, McCormick SA: Angioleiomyoma of the auricle: a rare tumor. Otolaryngol Head Neck Surg 2001, 125 : 109-110

3. Wang MC, Shiao AS: Auricle Angioleiomyoma. Chinese Medical Journal (Taipei) 2002, 65:180-182

4. Wirth GA, Sundine MJ, Kong AP, Carpenter PM: Auricular angioleiomyoma: a case report and review of the literature. Ear Nose Throat J 2007, 86:281-283
5. Hachisuga T, Hashimoto H, Enjoji M: Angioleiomyoma: a clinicopathologic reappraisal of 562 cases. Cancer 1984, 54: 126-130

6. Ramesh P, Annapureddy SR, Khan F, Sutaria PD: Angioleiomyoma: a clinical, pathological and radiological review. Int J Clin Pract 2004, 58:587-591

7. Weiss SW, Goldblum JR: Benign tumors of smooth muscle. Enzinger \& Weiss's Soft Tissue Tumors. 5th ed., Philadelphia, Mosby Elsevier, 2008, 517-528

8. Morimoto N: Angiomyoma (vascular leiomyoma): a clinicopathologic study. Medical Journal of Kagoshima University 1973, 24:663-683

9. Herren DB, Zimmermann A, Buchler $U$ : Vascular leiomyoma in an index finger undergoing malignant transformation. J Hand Surg Br 1995, 20B:484-487

10. Nishio J, Iwasaki H, Ohjimi Y, Ishiguro M, Kobayashi K, Nabeshima K, Naito M, Kikuchi M: Chromosomal imbalances in angioleiomyomas by comparative genomic hybridization. Int J Mol Med 2004, 13:13-16

11. Calonje E: Vascular tumors: Tumors and tumor-like conditions of blood vessels and lymphatics. In Elder DE (Ed): Lever's Histopathology of the Skin. 10th ed., Philadelphia, Lippincott Williams \& Wilkins, 2009, 1047-1051

12. Nall AV, Stringer SP, Baughman RA: Vascular leiomyoma of the superior turbinate: first reported case. Head Neck 1997, 19:63-67 